UDK: 355.01:050](497.5)"1991/2018" 930(497.5)"1991/2018" Pregledni članak

\title{
Domovinski rat u hrvatskim znanstvenim časopisima
}

\author{
DARJAN GODIĆ \\ Hrvatski institut za povijest, \\ Zagreb, Hrvatska \\ dgodic@isp.hr \\ DOMAGOJ KNEŽEVIĆ \\ Zagreb, Hrvatska \\ domagoj@isp.hr
}

\begin{abstract}
Autori analiziraju kako se u vodećim društveno-humanističkim znanstvenim časopisima u Hrvatskoj obrađivala tematika Domovinskoga rata. Kronološki je rad podijeljen na dva razdoblja: od 1991. do 1999. te od 2000. do 2018. godine. Rad ne sadržava bibliografiju znanstvenih i stručnih radova na temu Domovinskoga rata, nego samo one najvažnije koji su, prema mišljenju autora, pridonijeli boljem razumijevanju Domovinskoga rata.
\end{abstract}

Ključne riječi: Republika Hrvatska; Bosna i Hercegovina; Domovinski rat; detuđmanizacija; historiografija; znanost

\section{Uvod}

Povijesno razdoblje Domovinskoga rata iznimno je važno te je kao takvo predmet znanstvenih istraživanja. Važnost Domovinskoga rata za hrvatsko društvo dodatno je naglašena njegovim uvrštavanjem u izvorišne osnove Ustava Republike Hrvatske. ${ }^{1}$ Brojni znanstveni i stručni radovi svjedoče da je segment hrvatske historiografije koji se bavi temama iz Domovinskoga rata iznimno kvalitetan i razvijen. No, ovaj rad nije iscrpan pregled historiografskih znanstvenih radova s tematikom Domovinskoga rata, nego samo selek-

1 O značenju Domovinskoga rata za Republiku Hrvatsku svjedoče Deklaracija o Domovinskom ratu i Deklaracija o Oluji, koje je donio Hrvatski sabor. Više o sadržaju deklaracija u: „Deklaracija o Domovinskom ratu”, Narodne novine (Zagreb), 102 (2000), pristup ostvaren 22. 5. 2019., https://narodne-novine.nn.hr/clanci/sluzbeni/2000_10_102_1987.html; „Deklaracija o Oluji”, Narodne novine, 76 (2006), pristup ostvaren 22. 5. 2019., https://narodne-novine.nn.hr/ clanci/sluzbeni/2006_07_76_1787.html. 
tivni prikaz znanstvenih i stručnih radova koji se bave tom problematikom objavljenih u hrvatskim znanstvenim časopisima između 1991. i 2018. godine. Isto tako treba istaknuti da su razmatrani samo radovi objavljeni u Hrvatskoj bez obzira na to jesu li objavljeni na hrvatskom ili nekom stranom jeziku. Uz historiografske radove koji se u potpunosti bave problematikom Domovinskoga rata, analizirani su i oni koji se djelomično bave ovom temom i nastali su u okviru politologije, sociologije, prava i demografije. Stoga ovaj rad treba promatrati samo kao prilog znanstvenom bavljenju Domovinskim ratom. Nasuprot tome, nisu razmatrani prikazi knjiga, periodike i zbornika dokumenata te bilješke, osvrti i reagiranja. Razlog je taj što spomenute kategorije radova često nemaju znanstveni karakter i donose samo osnovne informacije. Što se tiče kronološke podjele, objavljena periodika o Domovinskom ratu može se podijeliti na dva razdoblja: od 1991. do 1999. i od 2000. pa sve do 2018. godine. Valja reći da je pomoću takve kronološke podjele moguće pratiti kako se mijenjao istraživački interes i pristup pojedinim temama. ${ }^{2}$

Domovinski rat u znanstvenim časopisima 1991. - 1999.

Domovinski rat, odnosno rat u Hrvatskoj, već je na samom početku privukao pozornost znanstvenih krugova u Hrvatskoj. U jeku srpske oružane pobune i agresije Srbije, Crne Gore i Jugoslavenske narodne armije (JNA) na Hrvatsku izašao je u prosincu 1991. broj politološkoga znanstvenog časopisa Politička misao u kojem su brojni povjesničari, politolozi i pravnici iznijeli ocjene o karakteru rata te analizu složenih društvenih i političkih prilika koje je rat prouzročio. Autori su se potrudili u što većoj mjeri objasniti i historijski kontekst hrvatsko-srpskih odnosa, a trenutačni rat definirali su kao agresiju Srbije na Hrvatsku. ${ }^{3}$ S obzirom na to da je rat očekivano privukao pozornost međunarodne zajednice i svjetskih medija, među kojima je vladala percepcija, ali i uvriježeno mišljenje da je rat samo posljedica dugotrajne međunacionalne mržnje između Hrvata i Srba, taj broj Političke misli bio je važan znanstveni i informacijski doprinos u rušenju tadašnjih stranih predrasuda o Hrvatskoj. Vrlo su brzo važnost Domovinskoga rata kao teme istraživanja prepoznali i časopisi usmjereni k istraživanju regionalne i zavičajne povijesti, među kojima treba istaknuti Dubrovačke horizonte i Domete. ${ }^{4}$

2 Potpunija bibliografija o Domovinskom ratu može se naći u: MILINKOVIĆ, „Kriza, rat, obnova: prilog bibliografiji”, 155-182; TATALOVIĆ, „Aktualna literatura”, 219-227; TATALOVIĆ, PRGOMET, „Selektivna bibliografija”, 141-199; LEŠČIĆ, Zbirka knjiga o Domovinskom ratu; LEŠČIĆ, Bilten prinova. God. I, br. 1/2009. (rujan/prosinac); LEŠČIĆ, Bilten prinova. God. II, br. 2 (siječanj/travanj 2010.); LEŠČIĆ, Bilten prinova. God. II, br. 3 (svibanj/prosinac 2010.); Online katalog Nacionalne i sveučilišne knjižnice u Zagrebu.

Naprimjer u: RODIN, „Politički i totalni rat”, 3-7; JAVOROVIĆ, „Rat u suvremenim uvjetima”, 13-31; CARATAN, „Rat i mir u Hrvatskoj”, 32-49; DEGAN, „Jugoslavija u raspadu”, 5061.

4 Vidi u: VIOLIĆ, „Ratna zbivanja u vrijeme okupacije Rijeke dubrovačke”, 86-96; VEŽIĆ, „Zadar na mapi rata”, 45-56; CRNIĆ-GROTIĆ, „Budućnost Hrvatske i sukcesija Jugoslavije”, 377-385. 
Iako je njegov utjecaj na društvena i politička gibanja u Hrvatskoj bio nesumnjivo prepoznat, u prvoj polovini devedesetih godina opseg historiografskih radova koji su se bavili problematikom Domovinskoga rata u znanstvenim časopisima nije bio proporcionalan njegovu povijesnom značenju, što je razumljivo jer je rat još uvijek trajao. Nasuprot tome, znanstveni radovi s tematikom Domovinskoga rata u Hrvatskoj bili su poprilično zastupljeni u onim znanstvenim časopisima u kojima su objavljivani radovi iz drugih znanstvenih područja. Pojedini takvi časopisi, poput Društvenih istraživanja, imali su cijele tematske brojeve posvećene Domovinskom ratu, u kojima su dominirale vojno-političke i društvene teme čija je važnost nadilazila regionalne i zavičajne okvire. O raznovrsnosti i brojnosti znanstvenih i stručnih radova u časopisima svjedoče prve objavljene bibliografije s radovima o Domovinskom ratu, koje uslijed tadašnjih tehničkih mogućnosti ipak nisu bile sustavne. ${ }^{5}$

Tadašnji pojačani istraživački interes nije uvijek pratila i kvaliteta radova zbog objektivnih poteškoća. Naime, pristup istraživača pojedinim istraživačkim temama određivala je dostupnost odnosno nedostupnost arhivske građe. Kao primarni izvori korišteni su televizijski prilozi, tiskovine te znanstvena literatura, koji su barem dijelom sadržavali relevantne podatke. Međutim, oskudni arhivski izvori i literatura nisu dopuštali nikakve dalekosežne zaključke. Arhivska građa srpske provenijencije bila je nedostupna iz razumljivih razloga, ali su neki autori uz ponešto truda uspijevali doći do srpskih tiskovina i relevantne literature. ${ }^{6} \mathrm{Iz}$ današnje perspektive za dio radova na prvi se pogled čini da su napisani bez argumenata i s unaprijed donesenim zaključcima, što predstavlja odmak od objektivne interpretacije ratnih zbivanja. No ako dotične radove sagledamo kroz prizmu tadašnjega društvenog i političkoga konteksta, postaje jasno da su napisani kao kritika politike predsjednika Tuđmana, odnosno hrvatskih vlasti. ${ }^{7}$

U drugoj polovini devedesetih godina najveći broj znanstvenih radova s tematikom Domovinskoga rata objavili su časopisi Politička misao i Društvena

5 O tome više u: MILINKOVIĆ, „Kriza, rat, obnova: prilog bibliografiji”, 155-182; ŠAKIĆ, „Zašto znanstveno istraživati srpsku agresiju na Hrvatsku 1991...?”, 215-216; KUMPES, „Nacionalizam, etnički sukob i rat”, 325-343; PRGOMET, „Hrvatsko ratno pismo”, 193-196. U drugom desetljeću 2000-ih, širenjem interneta, znanstveni časopisi uglavnom su prestali objavljivati bibliografije o Domovinskom ratu jer su bibliografske baze, arhivski izvori, znanstvena i stručna literatura postali široko dostupni.

6 TATALOVIĆ, „Military Aspects of the Peacekeeping Operation in Croatia”, 55-63.

7 Naprimjer u: JURČEVIĆ, „Vukovarski otpor srpskoj ratnoj agresiji”, 479-499; GORINŠEK et al., „Rat ili mir u Hrvatskoj”, 11-27. Jurčevićev rad ne sadržava bilješke, popis objavljenih izvora ni korištenu literaturu, ali je prvi rad na temu bitke za Vukovar objavljen u nekom hrvatskom znanstvenom časopisu te je prvi donio kronologiju bitke. U vrijeme njegova nastanka terminologija i metodologija istraživanja Domovinskoga rata još nije bila razrađena, pa je autor razne formacije neprijatelja poput milicije pobunjenih Srba, Teritorijalne obrane ili Jugoslavenske narodne armije nazivao četnicima i srpskom vojskom. Autor smatra da hrvatske civilne i vojne vlasti nisu pomagale obrani Vukovara i da je hrvatsko vrhovništvo spriječilo deblokadu opkoljenoga grada da bi steklo naklonost međunarodne zajednice. U radu „Rat ili mir u Hrvatskoj” autori raspravljaju je li rat bio dogovoren, s obzirom na razgovore Tuđmana i Miloševića u Karađorđevu, te je li mogao biti okončan već 1991. godine. 
istraživanja, a glavni fokus radova bio je na istraživanju vojnih, politoloških, socioloških i demografskih aspekata rata. ${ }^{8}$ Odabiru istraživačkih tema svakako je doprinijela činjenica što to nisu primarno historiografski časopisi jer objavljuju radove iz različitih društvenih i humanističkih disciplina. Tako je potpisivanje i provođenje Temeljnoga sporazuma o području istočne Slavonije, Baranje i zapadnoga Srijema u studenom 1995. potaknulo uredništva Političke misli i Društvenih istraživanja na izdavanje tematskih brojeva koji su se bavili povratkom prognanika i pitanjima mirne reintegracije. ${ }^{9}$

Fenomen Domovinskoga rata potaknuo je osnivanje sociološkoga znanstvenog časopisa Polemos, koji se trebao baviti isključivo istraživanjem problematike rata, pitanjima sigurnosti i hrvatske vojne povijesti. ${ }^{10} \mathrm{U}$ trenutku kada je u pojedinim znanstvenim časopisima jenjavao istraživački interes za Domovinski rat, Polemos je u dva broja 1998. objavio opsežan rad sociologa Ozrena Žuneca na temu rata u Hrvatskoj i Bosni i Hercegovini (BiH). Rad je nastao na ograničenom broju izvora, ali su u njemu prvi put izneseni detaljniji podaci o sukobljenim stranama i njihovim ratnim ciljevima te političkim i ratnim strategijama. Osim toga prvi je put iznesena detaljna kronologija srpske oružane pobune i agresije na Hrvatsku i BiH. U Polemosu je zatim 1998. objavljen i rad sociologa Tarika Kulenovića, koji je tematikom i pristupom bio sličan Žunecovu, a govorio je o početku i prvoj godini rata u $\mathrm{BiH} .{ }^{11}$ Polemos je objavljivanjem dijela znanstvenih članaka znatno utjecao i na drugačije pristupe sagledavanju problematike Domovinskoga rata. Jedan od tih pristupa bio je regionalni. Ovdje valja posebno izdvojiti rad umirovljenoga časnika Hrvatske vojske Vlade Hodalja, koji je 1999. objavio rad o operaciji „Vihor”, napadnoj akciji manjega opsega, ali poznatoj u široj javnosti zbog njezina neuspjeha $\mathrm{i}$ većega broja žrtava u redovima Hrvatske vojske. ${ }^{12}$

8 TATALOVIĆ, „Military and political aspects of the Croato-Serbian conflict”, 166-190; VUJEVIĆ, „Politička kultura i rat u Hrvatskoj i Bosni i Hercegovini”, 221-242. Vidi: AKRAP, „Koliko Hrvatska ima stanovnika nakon Domovinskog rata?”, 677.

9 Više u uvodnicima: CARATAN, „Kraj rata u Hrvatskoj”, 3-7; KALITERNA, „Prognana Hrvatska”, 193.

10 Vidi uvodnik: „Riječ čitateljima”, 7.

11 ŽUNEC, „Rat u Hrvatskoj 1991.-1995. 1. dio”, 57-87; ŽUNEC, „Rat u Hrvatskoj 1991.1995. 2. dio”, 111-136; KULENOVIĆ, „Pripreme za rat i početak rata u Bosni i Hercegovini”, 89112. Navedeni radovi najvećim su dijelom korektno i utemeljeno napisani uz korištenje znanstvenoga aparata, ali bez primarnih izvora.

12 HODALJ, „102. brigada Hrvatske vojske u operaciji Vihor”, 11-42. Autor je na temelju neobjavljene arhivske građe analizirao do tada vrlo ispolitiziranu temu u hrvatskoj javnosti. Rad je dao znanstveno utemeljene odgovore na određena pitanja, ali je pitanje znanstvene rasprave ostalo otvoreno. 
Novi pristup 2000-ih

Premda je u prethodno analiziranom razdoblju nastalo više vrijednih radova koji su se bavili problematikom Domovinskoga rata, u novom tisućljeću povećala se kvantiteta i kvaliteta radova u znanstvenim časopisima. Istraživačima su postali dostupni arhivi čija je građa omogućila uvid u događaje i procese ključne za razumijevanje historijskoga konteksta Domovinskoga rata. Osim što su otvorene nove teme, počela su se propitivati prije iznesena afirmativna ili kritička stajališta o pojedinim temama. ${ }^{13}$

Neosporno je u prvom desetljeću 2000-ih veliki utjecaj na znanstvena istraživanja Domovinskoga rata imao proces detuđmanizacije koji su pokrenuli političari i intelektualci neskloni politici Franje Tuđmana. Jedna od glavnih značajki detuđmanizacije bila je pojava društvene percepcije o postojanju kontroverznih epizoda Domovinskoga rata, poput navodne izdaje Vukovara ili dogovora Tuđmana i Miloševića o podjeli $\mathrm{BiH} .{ }^{14}$ No treba reći i da se Ivo Sanader, kao čovjek koji je naslijedio Tuđmana na čelu Hrvatske demokratske zajednice, priklonio procesu detuđmanizacije. Postoje viđenja koja tvrde da je sama navodna modernizacija stranke koju je proveo Sanader bila stanovita detuđmanizacija. Međutim, dugogodišnji Tuđmanov suradnik književnik Ivan Aralica ustvrdio je da je Sanader bio čovjek bez svojega izvornoga političkoga koncepta, koji se samo priklonio procesu detuđmanizacije kao trendu koji je tada pokazivao znakove političkoga uspjeha. ${ }^{15} \mathrm{~S}$ obzirom na to da je proces detuđmanizacije izazvao snažne društvene podjele, onom dijelu društva koji mu se žestoko protivio učinjen je ustupak započinjanjem znanstvenih istraživanja Domovinskoga rata. Primjerice, u Hrvatskom institutu za povijest započeo je 2001. projekt Stvaranje Republike Hrvatske i Domovinski rat 1991. - 1995. - 1998., koji je okončan 2006. godine. Zatim je 2004. osnovan Hrvatski memorijalno-dokumentacijski centar Domovinskog rata (HMDCDR), koji se uz prikupljanje i sređivanje arhivske građe bavi i znanstvenoistraživačkim radom. Kao rezultat svega u tim institucijama stasali su znanstvenici čija su istraživanja važan doprinos poznavanju tadašnjih vojnih i političkih odnosa, posebice Domovinskoga rata. ${ }^{16}$ Iznijet ćemo neke brojke. Po broju objavljenih radova $\mathrm{s}$ tematikom Domovinskoga rata u znanstvenim časopisima prednjači Davor Marijan iz Hrvatskoga instituta za povijest, koji se tijekom godina prometnuo

13 MARIJAN, „Bitka za Vukovar 1991., 367-402.

14 Više o procesu detuđmanizacije u: MARIJAN, „Suvremena hrvatska povijest i nevolje s revizionizmom", 397.

15 Darko HUDELIST, „Svi se na njega pozivaju, svatko ga tumači kako želi, ali ga malo tko razumije. Što je uopće tuđmanizam?”, Globus (Zagreb), on-line izdanje, 30. 9. 2019., pristup ostvaren 16. 10. 2019., https://www.jutarnji.hr/globus/Globus-politika/svi-se-na-njega-pozivaju-svatko-ga-tumaci-kako-zeli-ali-ga-malo-tko-razumije-sto-je-uopce-tudmanizam/9425042/.

16 MARIJAN, „Mitom protiv 'mita”, 440. O ozbiljnosti projekta u Hrvatskom institutu za povijest svjedoče njegovi konkretni rezultati. Objavljeno je pet školskih udžbenika, osam autorskih knjiga, deset poglavlja u knjigama i 39 znanstveno-stručnih radova u časopisima. U sklopu projekta nastale su tri disertacije i jedan magistarski rad. „Stvaranje Republike Hrvatske i Domovinski rat 1991. - 1995. - 1998." 
u jednoga od najboljih poznavatelja vojne i političke povijesti toga razdoblja. ${ }^{17}$ Objavljeni rezultati istraživanja znanstvenika iz Hrvatskoga instituta za povijest i HMDCDR-a potaknuli su izniman interes za teme o ratnim zbivanjima u Hrvatskoj i BiH. Primjerice, članak D. Marijana „Bitka za Vukovar 1991.” objavljen 2002. u časopisu Scrinia Slavonica do sada je preuzet 10153 puta, a članak Nikice Barića „Je li 1995. godine Hrvatska počinila 'etničko čišćenje' Srba?” objavljen 2004. u Časopisu za suvremenu povijest 3540 puta. ${ }^{18}$ Veliki broj preuzimanja imao je za posljedicu i povećanu citiranost radova. Tako je članak D. Marijana „Bitka za Vukovar 1991.” prema mrežnom pretraživaču znanstvenih radova Google Znalac do sada višekratno citiran u raznim monografijama, znanstvenim i stručnim radovima, doktorskim disertacijama i diplomskim radovima. ${ }^{19}$

Paralelno su se 2000-ih društveno-politička zbivanja izazvana detuđmanizacijom i odnosima između Hrvatske i Međunarodnoga suda za ratne zločine počinjene na području bivše Jugoslavije u Den Haagu odrazila na objavu radova s tematikom Domovinskoga rata $\mathrm{u}$ hrvatskim znanstvenim časopisima. Zbog pristupa problematici i otvorenosti prema tim temama Časopis za suvremenu povijest postao je jedan od vodećih znanstvenih časopisa kada je u pitanju historiografija o Domovinskom ratu. Uz prije objavljene radove, početkom 2004. izdao je dvojezični tematski broj koji se bavio angažmanom povjesničara na Haškom sudu. ${ }^{20}$ Tijekom sljedećih godina Časopis za suvremenu povijest nastavio je s izdavanjem takvih tematskih brojeva. Početkom 2008. objavljen je tematski broj „1990. - 1991. Prijelomne godine hrvatske povijesti: počeci Domovinskog rata”, a krajem 2015. tematski broj „Godina 1995. u suvremenoj hrvatskoj povijesti”. ${ }^{21}$ Slično su činili i drugi časopisi. National Security and the Future objavio je 2005. tematski broj koji se bavio ratom u $\mathrm{BiH}$, a Polemos se u broju iz 2006. bavio problematikom JNA. ${ }^{22}$

Ratna zbivanja u Hrvatskoj te osobito u BiH očekivano su zaokupljala pozornost međunarodne zajednice i svjetskih medija. Njihovim okončanjem pozornost je usmjerena $\mathrm{k}$ drugim kriznim žarištima u svijetu. Ipak, dio svjetskoga javnog mišljenja i pojedini inozemni povjesničari imali su predrasude o karakteru rata u Hrvatskoj i $\mathrm{BiH}$. Premda su predrasude postojale i prije, proces detuđmanizacije ih je produbio. Rješenje toga problema nudio je časopis

\footnotetext{
17 Navodimo samo najvažnije radove nastale u sklopu projekta Stvaranje Republike Hrvatske i Domovinski rat 1991. - 1995. - 1998. koji su objavljeni u znanstvenim časopisima. MARIJAN, „Jugoslavenska narodna armija u agresiji na Republiku Hrvatsku”, 289-321; MARIJAN, „Oružane snage SFRJ u izvanrednim prilikama”, 339-376; MARIJAN, „Sukob HVO-a i ABIH u Prozoru", 379-402.

18 Za broj preuzimanja i posjeta vidi: MARIJAN, „Bitka za Vukovar 1991.; BARIĆ, „Je li 1995. godine Hrvatska počinila ‘etničko čišćenje' Srba?”.

19 Vidi profil Davora Marijana na Google Znalcu.

20 „Haški sud za bivšu Jugoslaviju i povjesničari / ICTY and Historians”, Časopis za suvremenu povijest (dalje: $\check{C} S P) 36$ (2004), br. 1: 5-414.

${ }^{21} \check{C} S P 40$ (2008), br. 1: 5-294; ČSP 47 (2015), br. 3: 463-764.

22 „Impressum”, 1; Polemos 9 (2006), br. 17: 11-204.
} 
Review of Croatian History, koji je 2006. pokrenuo Hrvatski institut za povijest. Časopis je zamišljen kao publikacija u kojoj bi se na engleskom i drugim stranim jezicima inozemnim povjesničarima i široj stranoj javnosti bolje objasnile određene teme iz hrvatske povijesti, pa i Domovinskoga rata, koje su nerijetko bile pogrešno interpretirane i poimane. ${ }^{23}$

Svojevrsni nastavak znanstvenoga projekta Stvaranje Republike Hrvatske i Domovinski rat bio je znanstveni projekt Republika Hrvatska i Domovinski rat (1991. - 1995. - 2000.), koji je početkom 2007. započeo također u Hrvatskom institutu za povijest. Projekt je okončan krajem 2013. i rezultirao je boljim razumijevanjem raspada socijalističke Jugoslavije te ratova u Hrvatskoj i BiH kao jedne od složenijih tema europske povijesti XX. stoljeća. ${ }^{24}$ Radovi s tematikom Domovinskoga rata objavljeni u sklopu projekta i dalje su imali vojno-političku tematiku, ali su obrađivali i zbivanja unutar regionalnih i mjesnih okvira. ${ }^{25}$

$\mathrm{U}$ istraživanju ratnih zbivanja tijekom Domovinskoga rata na području istočne Hrvatske istaknula se Podružnica za povijest Slavonije, Srijema i Baranje Hrvatskoga instituta za povijest u Slavonskom Brodu. Podružnica je 2006. započela projekt Demokratski pokret, velikosrpska agresija $i$ Domovinski rat $u$ istočnoj Hrvatskoj, koji je okončan 2012. godine. ${ }^{26}$ Rezultati istraživanja znanstvenika na projektu većinom su objavljivani u časopisu Scrinia Slavonica i u njima dominiraju vojno-političke teme, ali s naglaskom na teme pojedinih sredina dijelova Slavonije, Baranje i zapadnoga Srijema. ${ }^{27}$ Slično kao Časopis za suvremenu povijest, Scrinia Slavonica postala je jedan od vodećih časopisa kada su u pitanju teme koje obrađuju Domovinski rat. U časopisu Radovi Zavoda za znanstvenoistraživački i umjetnički rad u Bjelovaru, koji izlazi od 2007., mogu se naći znanstveni članci o ratnim zbivanjima u bjelovarskom kraju i zapadnoj Slavoniji. Ovdje valja posebno istaknuti tematski broj iz 2014., u kojem su objavljena izlaganja sudionika znanstvenoga skupa Bjelovar i Bjelovarskobilogorska županija u Domovinskom ratu, koji se nametnuo kao nezaobilazan izvor za razumijevanje konteksta Domovinskoga rata u zapadnoj Slavoniji. ${ }^{28}$

${ }^{23}$ Navodimo samo dio radova. MARIJAN, „Aggression of the Yugoslav People’s Army”, 295318; SADKOVICH, „A historical test case”, 219-249; KRIŠTO, „Deconstructing a myth”, 3766; LUČIĆ, „The view from Bosnia and Herzegovina”, 67-84; BING, „Croatia's independence building”, 201-231; RAGUŽ, „'The Croats have no right to a state”, 143-152; MIŠKULIN, „An avoidable failure”, 37-77; BARIĆ, „The establishment and public activity of the Serbian People's Party in 1991", 79-102.

${ }^{24}$ Do njegova okončanja u sklopu projekta objavljeno je devet autorskih knjiga, 26 poglavlja u knjigama i 63 znanstveno-stručna rada u časopisima. U sklopu projekta nastale su i dvije disertacije. „Republika Hrvatska i Domovinski rat (1991. - 1995. - 2000.)”.

${ }_{25}$ MARIJAN, „'Slučaj' Logorište”, 453-480; LUČIĆ, „Duvno kao žarište ‘hrvatskog nacionalizma i katoličkog klerikalizma"', 571-602.

${ }^{26}$ U sklopu projekta nastalo je deset poglavlja u knjigama, dvije uredničke knjige i 44 znanstveno-stručna rada. Cjelovita bibliografija projekta može se naći u: „Demokratski pokret, velikosrpska agresija i Domovinski rat u istočnoj Hrvatskoj”.

${ }^{27}$ Kao najvažnije izdvajamo: BAŠIĆ, MIŠKULIN, „Grubišnopoljska kronika 1990.-1991. (I. dio)”, 342-370; BAŠIĆ, MIŠKULIN, „Grubišnopoljska kronika 1990.-1991. (II. dio)”, 454-494; BARAĆ, „Osnovna obilježja i okolnosti demokratizacije”, 419-453; MIŠKULIN, „Srpska pobuna u općini Pakrac", 355-392.

${ }^{28}$ Više u: Radovi Zavoda za znanstvenoistraživački i umjetnički rad u Bjelovaru (2014), br. 8: 17-542. 
Nakon gotovo desetljeće i pol dugog sudskog procesa Haški sud oslobodio je u studenom 2012. generale Antu Gotovinu i Mladena Markača. Sve do te oslobađajuće presude u medijima i javnosti nerijetko je bilo, u manjem dijelu i danas, interpretacija koje nisu bile utemeljene na povijesnim činjenicama. Upravo su hrvatski znanstveni časopisi bili među rijetkim publikacijama koje su nudile sagledavanje povijesne zbilje Domovinskoga rata utemeljeno na historiografskim metodama istraživanja. Nakon što su spomenuti znanstveni časopisi u prilikama političke i medijske nenaklonjenosti objavili brojne kvalitetne znanstvene i stručne radove utemeljene na istraživanjima arhivske građe o Domovinskom ratu, istraživačima je poslije 2012. postalo vrlo teško doći do arhivske građe hrvatske provenijencije. Premda su hrvatske državne institucije, poštujući zakon o suradnji s Haškim sudom, predale sudu veliku količinu dokumenata, suradnja nije uvijek bila u skladu s nacionalnim interesima. Tako se veliki dio važnih državnih dokumenata može naći na mrežnim stranicama toga suda, a u Hrvatskoj su i dalje klasificirani kao tajni. ${ }^{29}$

Zbog otežanoga pristupa arhivskoj građi hrvatske provenijencije dio povjesničara, osobito oni mlađe generacije, usmjerio je istraživački interes prema građi nastaloj djelovanjem JNA te civilnih i vojnih institucija pobunjenih Srba. ${ }^{30}$ Ta se građa do osnivanja HMDCDR-a čuvala u hrvatskim civilnim i vojnim sigurnosnim službama i Hrvatskom državnom arhivu u Zagrebu. ${ }^{31}$ Valja napomenuti da taj interes znači iskorak prema boljem razumijevanju historijskoga konteksta Domovinskoga rata jer se sustavnim istraživanjem vojno-političkih i društvenih prilika u Republici Srpskoj Krajini dobiva jasnija slika o naravi i tijeku srpske oružane pobune i agresije na Hrvatsku. Objavljeni znanstveni radovi pridonijeli su stvaranju novih perspektiva za istraživanje problematike Domovinskoga rata jer su povjesničari mlađe generacije napravili odmak od tada dominantnih tema. Dok su starije generacije povjesničara istraživale uzroke srpske oružane pobune, tijek agresije te najvažnije vojnopolitičke događaje, mlađe su počele istraživati teme iz demografije, vojne geografije i kaznene politike na okupiranim područjima Hrvatske i o tome objavljivati radove $\mathrm{u}$ hrvatskim znanstvenim časopisima. ${ }^{32}$

${ }^{29}$ HOLJEVAC TUKOVIĆ, „Arhiv Međunarodnog kaznenog suda u Haagu”, 336-337; MARIJAN, „Mitom protiv 'mita”, 440.

${ }^{30}$ Naprimjer u: NAZOR, SEKULA GIBAČ, „Proces pokušaja normalizacije hrvatsko-srpskih odnosa”, 7-36; ŠTEFANČIĆ, „Osnovno i srednje školstvo na okupiranom području”, 69-105; VUČUR, „Pogibija Gorana Alavanje”, 587-607.

31 Većina arhivske građe u HMDCDR-u arhivistički je obrađena te sređena u fondove i zbirke s pripadajućim inventarima, što olakšava istraživanja. Dio navedene građe može se naći u zbornicima dokumenata Republika Hrvatska i Domovinski rat 1990. - 1995., koje je objavio HMDCDR. Dosad je objavljeno 20 zbornika.

32 SABOLOVIĆ, SAMODOL, „Vojno-geografska analiza”, 523-542; SEKULA GIBAČ, RUŽIĆ, „Izravni demografski gubici stanovništva Republike Srpske Krajine”, 543-562; GOLEK, PETKOVIĆ, „Kazna u Krajini”, 29-57. 
Često se u hrvatskom medijskom prostoru može pročitati ili čuti da se „istina o Domovinskom ratu ne smije prešućivati”. ${ }^{33}$ Možda se „istina” prešućuje, ali se o Domovinskom ratu itekako piše. U hrvatskim znanstvenim časopisima od 2000. pa sve do 2016. objavljeno je preko stotinu znanstvenih radova na temu Domovinskoga rata nastalih u okrilju društveno-humanističkih znanosti. Dakle, unatoč znanstveno neutemeljenim tvrdnjama koje se mogu naći u pojedinim medijima, povjesničari su napravili izniman posao, o čemu svjedoči kvantiteta i kvaliteta objavljenih radova u znanstvenim časopisima. ${ }^{34}$

Kakve su perspektive u daljnjim istraživanjima problematike Domovinskoga rata? Teško je sa sigurnošću predvidjeti trendove, ali može se pretpostaviti da se interes istraživača za proučavanje razdoblja Domovinskoga rata neće smanjivati. No istraživanja se više ne mogu svoditi samo na vojno-političke teme, nego je potreban pomak prema istraživanjima koja bi obuhvatila ulogu političkih stranaka, gospodarstva, žena, nacionalnih manjina ili međunarodne zajednice u ratu. Izvjesno je da će istraživanja pojedinih tema ovisiti o dostupnosti arhivske građe, i one koja se čuva u hrvatskim arhivima i one u stranima. Ipak, nedostupnost arhivske građe istraživači mogu dijelom nadomjestiti korištenjem tiska, literature, statističkih podataka ili metodom usmene povijesti, koja je poprilično zapostavljena u istraživanju događaja Domovinskoga rata. ${ }^{35}$ Osim cjelovitijih interpretacija Domovinskoga rata, primjena usmene povijesti može uroditi i istraživanjima uloge pojedinca ili manjih grupa u borbi, što odgovara formi mikrohistorije. Na kraju se može zaključiti da postoji niz zanemarenih tema koje tek treba istražiti.

\section{Zaključak}

Kada se $\mathrm{u}$ analiziranom razdoblju u znanstvenim časopisima pogleda broj radova koji tematiziraju Domovinski rat, nema sumnje da su hrvatski znanstvenici napravili velik posao usprkos mnogim problemima koji su pratili njihova istraživanja. Ti problemi dijelom su bili političke prirode (primjerice, velika količina arhivske građe dostavljena je Haškom sudu te dugo nije bila dostupna hrvatskim znanstvenicima), ali bilo je i realnih istraživačkih problema kada bi hrvatske institucije istraživačima uskratile uvid u arhivsku građu držeći se zakona o dostupnosti arhivskoga gradiva.

Kronološki je analiza u ovom radu podijeljena na razdoblje od 1991. do 2000. i od 2000. do 2018. godine. Od 1991. do 2000. znanstveni radovi s tematikom Domovinskoga rata u hrvatskim znanstvenim časopisima nisu bili

\footnotetext{
33 „25 godina od mučkog ubojstva 12 redarstvenika u Borovu”.

34 Dovoljno je posjetiti mrežne stranice Nacionalne i sveučilišne knjižnice u Zagrebu, ali je gornja granična godina za pretragu serijskih publikacija u Nacionalnoj i sveučilišnoj knjižnici 2016. Vidi: Pretraživač novih naslova pristiglih u čitaonice Nacionalne i sveučilišne knjižnice u Zagrebu.

${ }^{35}$ O usmenoj povijesti Domovinskoga rata vidi: BENČIĆ, „Osobna sjećanja”, 341-362.
} 
brojni zbog nedostupnosti arhivskoga gradiva. Isto tako dio radova imao je očekivano pristran autorski pristup. U tom razdoblju najveći broj znanstvenih radova s tematikom Domovinskoga rata objavljen je u časopisima Politička misao, Društvena istraživanja i Polemos. Zbog nemogućnosti pristupa izvornoj arhivskoj građi o tome su mnogo više pisali sociolozi, politolozi i pravnici.

Tijekom 2000., odnosno nakon smrti predsjednika Tuđmana, na hrvatskoj društvenoj sceni započela je detuđmanizacija. Na unutarnjem planu provodili su ju Tuđmanovi politički protivnici uz snažnu potporu dijela međunarodne zajednice kroz rad Haškoga suda. Jedna od značajki detuđmanizacije bilo je negiranje činjenica u vezi s Domovinskim ratom. Također je Haški sud podizao optužnice protiv generala Hrvatske vojske te vojnoga i političkoga vodstva Hrvata u BiH. Čini se da je pojavu velikoga broja kvalitetnih historiografskih znanstvenih radova s tematikom Domovinskoga rata u hrvatskim znanstvenim časopisima potaknula upravo detuđmanizacija te podizanje haških optužnica. Naime, koalicijska vlada Ivice Račana odobrila je pokretanje znanstvenih projekata u Hrvatskom institutu za povijest te njegovoj podružnici u Slavonskom Brodu koji su primarno bili posvećeni istraživanju Domovinskoga rata. Motivi za tu odluku bili su neosporno dnevnopolitički. Ipak, znanstveni časopisi čiji su izdavači bili Hrvatski institut za povijest i njegova podružnica u Slavonskom Brodu objavili su tijekom 2000-ih i 2010-ih najviše znanstvenih radova s tematikom Domovinskoga rata, od kojih i danas mnogi imaju visoku znanstvenu razinu.

\section{Literatura i tisak}

AKRAP, Anđelko. „Koliko Hrvatska ima stanovnika nakon Domovinskog rata?” Društvena istraživanja: časopis za opća društvena pitanja 8 (1999), br. 5-6 (43-44): 677.

BARAĆ, Mladen. „Osnovna obilježja i okolnosti demokratizacije društveno-političkog života slavonskobrodske općine tijekom 1990." Scrinia Slavonica: godišnjak Podružnice za povijest Slavonije, Srijema i Baranje Hrvatskog instituta za povijest 10 (2010), br. 1: 419-453.

BARIĆ, Nikica. „Je li 1995. godine Hrvatska počinila 'etničko čišćenje' Srba?" Časopis za suvremenu povijest 36 (2004), br. 2: 441-461. Pristup ostvaren 4. 7. 2019. https://hrcak.srce.hr/744.

BARIĆ, Nikica. „The establishment and public activity of the Serbian People's Party in 1991". Review of Croatian History 7 (2011), br. 1: 79-102.

BAŠIĆ, Petar; MIŠKULIN, Ivica. „Grubišnopoljska kronika 1990.-1991. (I. dio)". Scrinia Slavonica: godišnjak Podružnice za povijest Slavonije, Srijema $i$ Baranje Hrvatskog instituta za povijest 7 (2007), br. 1: 342-370.

BAŠIĆ, Petar; MIŠKULIN, Ivica. „Grubišnopoljska kronika 1990.-1991. (II. dio)". Scrinia Slavonica: godišnjak Podružnice za povijest Slavonije, Srijema i Baranje Hrvatskog instituta za povijest 10 (2010), br. 1: 454-494. 
BENČIĆ, Andriana. „Osobna sjećanja sudionika i sudionica Domovinskog rata”. Društvena istraživanja: časopis za opća društvena pitanja 26 (2017), br. 3: 341-362. Pristup ostvaren 4. 7. 2019. DOI: 10.5559/di.26.3.02.

BING, Albert. „Croatia's independence building: between principle and realpolitik”. Review of Croatian History 7 (2011), br. 1: 201-231.

CARATAN, Branko. „Kraj rata u Hrvatskoj: Vukovar 1991. - 1998.” Politička misao: časopis za politologiju 35 (1998), br. 1: 3-7.

CARATAN, Branko. „Rat i mir u Hrvatskoj”. Politička misao: časopis za politologiju 28 (1991), br. 4: 32-49.

CRNIĆ-GROTIĆ, Vesna. „Budućnost Hrvatske i sukcesija Jugoslavije”. Dometi: časopis za kulturu i društvena pitanja 25 (1992), br. 9-10: 377-386.

Časopis za suvremenu povijest 36 (2004), br. 1: 5-414.

Časopis za suvremenu povijest 40 (2008), br. 1: 5-294.

Časopis za suvremenu povijest 47 (2015), br. 3: 463-764.

DEGAN, Vladimir Đuro. „Jugoslavija u raspadu. Mišljenje arbitražne komisije br. 1. od 7. prosinca 1991.” Politička misao: časopis za politologiju 28 (1991), br. 4: 50-61.

Globus (Zagreb), 2019.

GOLEK, Kristina; PETKOVIĆ, Krešimir. „Kazna u Krajini. Prilog istraživanju povijesti političke moći i kažnjavanja na području Hrvatske 1991. 1995." Ćasopis za suvremenu povijest 49 (2017), br. 1: 29-57. Pristup ostvaren 4. 7. 2019. DOI: $10.22586 /$ csp.v49i1.8.

GORINŠEK, Karl; ŠPEGELJ, Martin; TRIPALO, Miko; ŽUNEC, Ozren. „Rat ili mir u Hrvatskoj”. Erasmus: časopis za kulturu demokracije (1993), br. 4: 11-27.

HODALJ, Vlado. „102. brigada Hrvatske vojske u operaciji Vihor 1991. godine”. Polemos: časopis za interdisciplinarna istraživanja rata i mira 2 (1999), br. 3-4: 11-43.

HOLJEVAC TUKOVIĆ, Ana. „Arhiv Međunarodnog kaznenog suda u Haagu, njegov značaj i dostupnost za arhiviste i istraživače”. Arhivski vjesnik 57 (2014), br. 1: 333-347.

„Impressum”. National Security and the Future 6 (2005), br. 3-4: 1.

JAVOROVIĆ, Božidar. „Rat u suvremenim uvjetima”. Politička misao: časopis za politologiju 28 (1991), br. 4: 13-32.

JURČEVIĆ, Josip. „Vukovarski otpor srpskoj ratnoj agresiji na Hrvatsku 1991...". Društvena istraživanja: časopis za opća društvena pitanja 2 (1993), br. 2-3: 479-499.

KALITERNA, Ljiljana. „Prognana Hrvatska”. Društvena istraživanja: časopis za opća društvena pitanja 6 (1997), br. 2-3 (28-29): 193. 
KARAULA, Željko. „'Demokracija je počela’: demokratski izbori u Općini Bjelovar 1990. godine”. Radovi Zavoda za znanstvenoistraživački i umjetnički rad u Bjelovaru (2008), br. 2: 287-305.

KRIŠTO, Jure. „Deconstructing a myth: Franjo Tuđman and Bosnia and Herzegovina”. Review of Croatian History 6 (2010), br. 1: 37-66.

KULENOVIĆ, Tarik. „Pripreme za rat i početak rata u Bosni i Hercegovini 1992. godine”. Polemos: časopis za interdisciplinarna istraživanja rata i mira 1 (1998), br. 1: 89-112.

KUMPES, Josip. „Nacionalizam, etnički sukob i rat: selektivna bibliografija (1991-1993)”. Migracijske i etničke teme 12 (1993), br. 1-2: 325-343.

LEŠČIĆ, Jelica, ur. Bilten prinova Zbirke knjiga o Domovinskom ratu Nacionalne i sveučilišne knjižnice u Zagrebu. Katalog. God. I, br. 1/2009. (rujan/ prosinac). Zagreb: Nacionalna i sveučilišna knjižnica u Zagrebu, 2010.

LEŠČIĆ, Jelica, ur. Bilten prinova Zbirke knjiga o Domovinskom ratu Nacionalne i sveučilišne knjižnice u Zagrebu. God. II, br. 2 (siječanj/travanj 2010.). Zagreb: Nacionalna i sveučilišna knjižnica u Zagrebu, 2010.

LEŠČIĆ, Jelica, ur. Bilten prinova Zbirke knjiga o Domovinskom ratu Nacionalne i sveučilišne knjižnice u Zagrebu. God. II, br. 3 (svibanj/prosinac 2010.). Zagreb: Nacionalna i sveučilišna knjižnica u Zagrebu, 2011.

LEŠČIĆ, Jelica, ur. Zbirka knjiga o Domovinskom ratu Nacionalne i sveučilišne knjižnice u Zagrebu. Zagreb: Nacionalna i sveučilišna knjižnica u Zagrebu, 2009.

LUČIĆ, Ivica. „Duvno kao žarište 'hrvatskog nacionalizma i katoličkog klerikalizma’ u zadnjem desetljeću komunističke vlasti”. Časopis za suvremenu povijest 44 (2012), br. 3: 571-602.

LUČIĆ, Ivo. „The view from Bosnia and Herzegovina on Franjo Tuđman's 'Bosnian policy"'. Review of Croatian History 6 (2010), br. 1: 67-84.

MARIJAN, Davor. „Aggression of the Yugoslav People's Army on the Republic of Croatia 1990-1992". Review of Croatian History 1 (2005), br. 1: 295318.

MARIJAN, Davor. „Bitka za Vukovar 1991” Scrinia Slavonica: godišnjak Podružnice za povijest Slavonije, Srijema i Baranje Hrvatskog instituta za povijest 2 (2002), br. 1: 367-402. Pristup ostvaren 4. 7. 2019. https://hrcak.srce. $\mathrm{hr} / 11352$.

MARIJAN, Davor. „Jugoslavenska narodna armija u agresiji na Republiku Hrvatsku 1990. - 1992. godine”. Časopis za suvremenu povijest 33 (2001), br. 2: 289-321.

MARIJAN, Davor. „Mitom protiv 'mita' ili o knjizi Rat $i$ mit Dejana Jovića”. Časopis za suvremenu povijest 50 (2018), br. 2: 435-452.

MARIJAN, Davor. „Oružane snage SFRJ u izvanrednim prilikama”. Časopis za suvremenu povijest 34 (2002), br. 2: 339-376. 
MARIJAN, Davor. „Slučaj' Logorište”. Časopis za suvremenu povijest 43 (2011), br. 2: 453-480.

MARIJAN, Davor. „Sukob HVO-a i ABIH u Prozoru, u listopadu 1992.” Časopis za suvremenu povijest 38 (2006), br. 2: 379-402.

MARIJAN, Davor. „Suvremena hrvatska povijest i nevolje s revizionizmom”. Časopis za suvremenu povijest 51 (2019), br. 2: 385-420. Pristup ostvaren 20. 9. 2019. DOI: 10.22586/csp.v51i2.9120.

MILINKOVIĆ, Bosiljka. „Kriza, rat, obnova: prilog bibliografiji”. Sociologija sela: časopis za istraživanje prostornoga i sociokulturnog razvoja (1992), br. 115-116: 155-182.

MIŠKULIN, Ivica. „An avoidable failure: peacekeeping in Croatia”. Review of Croatian History 7 (2011), br. 1: 37-77.

MIŠKULIN, Ivica. „Srpska pobuna u općini Pakrac 1990.-1991.: uzroci, nositelji i tijek". Scrinia Slavonica: godišnjak Podružnice za povijest Slavonije, Srijema i Baranje Hrvatskog instituta za povijest 11 (2011), br. 1: 355-392.

Narodne novine (Zagreb), 102 (2000), 76 (2006).

NAZOR, Ante; SEKULA GIBAČ, Janja. „Proces pokušaja normalizacije hrvatsko-srpskih odnosa i mirne reintegracije Republike Srpske Krajine 1994./1995. na okupiranom području zapadne Slavonije”. Časopis za suvremenu povijest 46 (2014), br. 1: 7-36.

Polemos: časopis za interdisciplinarna istraživanja rata i mira 9 (2006), br. 17: 11-204.

PRGOMET, Josip. „Hrvatsko ratno pismo: kratki pregled bibliografija o ratu u Hrvatskoj i BiH”. Polemos: časopis za interdisciplinarna istraživanja rata i mira 1 (1998), br. 1: 193-196.

Radovi Zavoda za znanstvenoistraživački $i$ umjetnički rad u Bjelovaru (2014), br. 8: 17-542.

RAGUŽ, Jakša. "'The Croats have no right to a state' - Serbian historiography, autobiographers, and publicists on Croatian state independence". Review of Croatian History 7 (2011), br. 1: 143-152.

„Riječ čitateljima”. Polemos: časopis za interdisciplinarna istraživanja rata $i$ mira 1 (1998), br. 1: 7-8.

RODIN, Davor. „Politički i totalni rat”. Politička misao: časopis za politologiju 28 (1991), br. 4: 3-7.

SABOLOVIĆ, Marin; SAMODOL, Krešimir. „Vojno-geografska analiza područja odgovornosti Operativne grupe Sjever Zbornoga područja Split u operaciji 'Oluja'”. Časopis za suvremenu povijest 47 (2015), br. 3: 523-542.

SADKOVICH, James J. „A historical test case: was Franjo Tuđman an authoritarian nationalist?" Review of Croatian History 3 (2007), br. 1: 219-249.

SEKULA GIBAČ, Janja; RUŽIĆ, Slaven. „Izravni demografski gubici stanovništva Republike Srpske Krajine tijekom i neposredno nakon hrvatskih 
oslobodilačkih operacija 'Bljesak' i ‘Oluja' 1995. godine”. Časopis za suvremenu povijest 47 (2015), br. 3: 543-562.

ŠAKIĆ, Vlado. „Zašto znanstveno istraživati srpsku agresiju na Hrvatsku 1991...?" Društvena istraživanja: časopis za opća društvena pitanja 2 (1993), br. 2-3 (10-11): 215-216.

ŠTEFANČIĆ, Domagoj. „Osnovno i srednje školstvo na okupiranom području Republike Hrvatske 1991. - 1995.” Anali za povijest odgoja 14 (38) (2015), br. 14: 69-105.

ŠTEFŠA, Željka. „Demografska kretanja stanovništva daruvarskoga kraja u razdoblju od 1857. do 2001. godine". Radovi Zavoda za znanstvenoistraživački i umjetnički rad u Bjelovaru (2008), br. 2: 253-263.

TATALOVIĆ, Siniša. „Aktualna literatura: Selektivna bibliografija knjiga i članaka o ratu u Hrvatskoj”. Politička misao: časopis za politologiju 32 (1995), br. 3-4: 219-227.

TATALOVIĆ, Siniša. „Military and political aspects of the Croato-Serbian conflict”. Politička misao: časopis za politologiju 33 (1996), br. 5: 166-190.

TATALOVIĆ, Siniša. „Military Aspects of the Peacekeeping Operation in Croatia”. Politička misao: časopis za politologiju 30 (1993), br. 2: 55-63.

TATALOVIĆ, Siniša; PRGOMET, Josip. „Selektivna bibliografija knjiga o ratovima na prostoru bivše SFRJ, 1991. - 1998.". Polemos: časopis za interdisciplinarna istraživanja rata i mira 1 (1998), br. 2: 141-199.

VEŽIĆ, Pavuša. „Zadar na mapi rata”. Dometi: časopis za kulturu i društvena pitanja 25 (1992), br. 1-2: 45-56.

VIOLIĆ, Nikola. „Ratna zbivanja u vrijeme okupacije Rijeke dubrovačke”. Dubrovački horizonti: časopis Društva Dubrovčana i prijatelja dubrovačke starine u Zagrebu (1992), br. 32: 86-96.

VUČUR, Ilija. „Pogibija Gorana Alavanje 23. studenoga 1990.: događaj, interpretacije, manipulacije". Časopis za suvremenu povijest 49 (2017), br. 3: 587-607. Pristup ostvaren 4. 7. 2019. DOI: 10.22586/csp.v49i3.20.

VUJEVIĆ, Miroslav. „Politička kultura i rat u Hrvatskoj i Bosni i Hercegovini”. Politička misao: časopis za politologiju 33 (1996), br. 4: 221-242.

ŽUNEC, Ozren. „Rat u Hrvatskoj 1991.-1995. 1. dio: uzroci rata i operacije do sarajevskog primirja”. Polemos: časopis za interdisciplinarna istraživanja rata i mira 1 (1998), br. 1: 57-87.

ŽUNEC, Ozren. „Rat u Hrvatskoj 1991.-1995. 2. dio: od sarajevskog primirja do završnih operacija”. Polemos: časopis za interdisciplinarna istraživanja rata i mira 1 (1998), br. 2: 111-136. 


\section{Internetski izvori}

„25 godina od mučkog ubojstva 12 redarstvenika u Borovu: Istina o Domovinskom ratu ne smije se prešućivati”. Portal Narod.hr, 2. 5. 2016. Pristup ostvaren 22. 5. 2019. https://narod.hr/hrvatska/foto-25-godina-od-muckogubojstva-12-redarstvenika-u-borovu-istina-o-domovinskom-ratu-ne-smijese-presucivati.

„Demokratski pokret, velikosrpska agresija i Domovinski rat u istočnoj Hrvatskoj”. CROSBI. Pristup ostvaren 22. 5. 2019. http://bib.irb.hr/listaradova?sif_proj=252-2522632-2626\&period=2007\# casopis.

„Odlikovani kanadski vojnici koji su se 'branili od Hrvata”. Portal Index. hr, 3. 12. 2002. Pristup ostvaren 20. 4. 2019. https://www.index.hr/vijesti/clanak/odlikovani-kanadski-vojnici-koji-su-se-branili-od-hrvata/105454.aspx.

Online katalog Nacionalne i sveučilišne knjižnice u Zagrebu. Pristup ostvaren 25. 4. 2019. http://katalog.nsk.hr/F/9X7TR35UX1LMII187LIK1HBL LLA1VRVU68Y3VTVHNSB7896CVH-36409? func=find-d-0.

Pretraživač novih naslova pristiglih u čitaonice Nacionalne i sveučilišne knjižnice u Zagrebu. Pristup ostvaren 22. 5. 2019. http://iks.nsk.hr/bilten_prinova/?_ga=2.227094110.2101648828.1563442253-1447138913.1563442253.

Profil Davora Marijana. Google Znalac. Pristup ostvaren 4. 7. 2019. https:// scholar.google.hr/citations?hl=hr\&user=rQvaUK0AAAAJ.

„Republika Hrvatska i Domovinski rat (1991. - 1995. - 2000.)”. CROSBI. Pristup ostvaren 22. 5. 2019. https://www.bib.irb.hr/pregled/projekti/0190190609-0586? page $=1$.

„Stvaranje Republike Hrvatske i Domovinski rat 1991. - 1995. - 1998.” Pristup ostvaren 22. 5. 2019. https://www.bib.irb.hr/pretraga?operators=and\% 7C0019045\%7Ctext\%7Cproject\&page $=1$.

Sudski spisi Međunarodnog kaznenog suda za bivšu Jugoslaviju u Den Haagu. Pristup ostvaren 20. 4. 2019. http://icr.icty.org/default.aspx. 


\section{SUMMARY}

\section{The Croatian War of Independence in Croatian Academic Journals}

The Croatian War of Independence is of exceptional importance to Croatian society, but is often the subject of controversial interpretations. Most controversies have been resolved via scientific and professional papers published in Croatian academic journals. Therefore, this work presents a selective overview of the most significant scientific and professional papers on the Croatian War of Independence published in the leading social sciences and humanities journals in Croatia. In addition to the most important historiographical works on the Croatian War of Independence, the authors have analysed works from the fields of political science, sociology, law, and demographics that partially address the War. They have divided this paper into two chronological periods, in which they have analysed the changing of research interests and approaches to the topic of the war in Croatia. During the 1990s, the greatest part of the works on the Croatian War of Independence were published in the journals Politička misao, Društvena istraživanja, and Polemos. Despite objective difficulties, such as the inaccessibility of archival material, the mentioned journals contain quality works that have contributed towards a better understanding of the historical context of the Croatian War of Independence. The 2000 s were marked by the process of de-Tuđmanisation, whose main characteristic was the denial of facts regarding the Croatian War of Independence. Although it negatively affected the social and political conditions in Croatia, de-Tuđmanisation resulted in numerous quality works covering the Croatian War of Independence, published in academic journals such as the Journal of Contemporary History, National Security and the Future, and Scrinia Slavonica. In contrast to public media and politics, the authors of these works approached the context of the Croatian War of Independence from outside the frame of daily politics. After the collapse of de-Tuđmanisation, researchers' access to a significant part of archival material of Croatian provenance has become more difficult, prompting them to turn to archival material created by the activities of the Yugoslav People's Army and rebel Serb civilian and military institutions, kept at the Croatian Memorial-Documentation Centre for the Homeland War. Despite all difficulties, the Croatian War of Independence is a promising period for academic research, as is attested to by the exceptional interest shown by researchers.

Key words: Republic of Croatia; Bosnia and Herzegovina; Croatian War of Independence; de-Tuđmanisation; historiography; research 